\title{
The Rise and Spread of Behavioral Public Policy: An Opportunity for Critical Research and Self- Reflection
}

\section{Holger Straßheim}

\section{(2) OpenEdition \\ Journals}

Electronic version

URL: http://journals.openedition.org/irpp/897

DOI: $10.4000 /$ irpp. 897

ISSN: 2706-6274

\section{Publisher}

International Public Policy Association

\section{Printed version}

Date of publication: 27 April 2020

Number of pages: 115-128

ISSN: 2679-3873

\section{Electronic reference}

Holger Straßheim, «The Rise and Spread of Behavioral Public Policy: An Opportunity for Critical Research and Self-Reflection », International Review of Public Policy [Online], 2:1 | 2020, Online since 27 April 2020, connection on 11 June 2020. URL : http://journals.openedition.org/irpp/897 ; DOI : https:// doi.org/10.4000/irpp.897

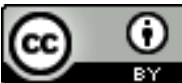

International Review of Public Policy is licensed under a Creative Commons Attribution 4.0 International. 


\section{The Rise and Spread of Behavioral Public Policy: An Opportunity for Critical Research and Self-Reflection}

\section{Holger Straßheim}

Professor of Political Sociology and Co-Director of the Institute for World Society Studies at Bielefeld University.

\section{Abstract}

Some argue that the global rise of behavioral approaches challenges the rationalist tradition in public policy. Others fear that it could undermine deliberation and public reasoning. This paper focuses on the worldwide rise and spread of behavioral expertise and behavioral public policy. It provides a general insight in terms of the role of expertise, the science-policy nexus and the distribution of epistemic competences in public policy. Based on an extensive literature review, the emergence and consequences of behavioral-expert networks are assessed. It will be suggested that it is necessary to break free from the microfocus proposed by behavioral public policy and to pay more attention to the institutional and cultural constellations of knowledgeand decision-making in democracies.

\section{Keywords}

behavioral public policy, nudging, expertise, epistemic communities, instrument constituencies, epistocracy, deliberative democracy 


\section{Introduction}

Over the past 70 years, public policy has always been closely interlinked with the study of human behavior. Following a temporal pattern of recurring waves that suggests the existence of issue-attention cycles among academics, top public policy journals were repeatedly fascinated by psychological and behavioral analysis (for a bibliometric analysis, see Rawat, 2019). Major contributions by scholars such as Lasswell (1951), Simon (1957) and Lindblom (1959) provided a deep understanding of cognitive limitations in decision-making. In the 1970s, policy experts were already discussing non-regulatory interventions to influence behavior in trafficsafety regulation, environmental protection and health policy (Graf, 2019). When, in the late 1970s and early 1980s, Kahnemann, Tversky and others contributed to the emerging field of behavioral economics with their experimental findings on 'heuristics and biases', both public policy analysis and practice could already build on a rich and controversial debate concerning behavioral perspectives (Straßheim, 2019b; Torgerson, 2019).

In the past decade, however, there has been a remarkable increase in behavioral studies and interventions in public policy on a global scale (for an overview, see Straßheim \& Beck, 2019). Public-policy journals are publishing more experimental studies than before and the interest in behavioral research seems to equal that in top economic journals (Rawat, 2019, p. 55). The OECD has concluded that behavioral approaches in public policy are 'more than a fashionable foray' and 'have taken root in many ways across many countries around the world and across a wide range of sectors and policy areas' (OECD, 2017, p. 13).

Behavioral public policy, as understood here, includes all means and modes of public policy aiming at influencing human behavior by using insights from behavioral economics, behavioral sciences, psychology or neurosciences. The spectrum of policy instruments is large, including governmental simplification to reduce the cognitive burden on citizens, risk-education programmes, techniques of social-norms marketing and behaviorally informed regulation to prevent the industry from manipulating consumers (Howlett, 2019; Loer, 2019; Oliver, 2015). Nudges are probably the most prominent subtype of behavioral public policy (Thaler \& Sunstein, 2008): the rearrangement of fruit and vegetables in cafeterias to focus our attention on healthy options; graphic warnings on cigarette packages; messages to stop people from using too many paper towels, or urging them to switch off the light when they leave the office - these and other interventions have become part of everyday life.

While the US, the UK and Singapore are among the forerunners, behavioral public policies can nowadays be found in many countries across Western Europe, Central America, Asia, Africa and the Middle East. In more than 70 behavior-expert organizations, mostly organized as small teams in chancelleries, as consultancies, or as networks between ministries, behavioral insights are translated into policies (John, 2018). The close entanglement of scientific and political claims, of analysing and governing behavior, is a common feature of all forms of behavioral public policy. Expertise and evidence-based policy have become essential resources for this movement (Straßheim, Jung, \& Korinek, 2015). The awarding of the Sveriges Riksbanks Prize in Economic Sciences in Memory of Alfred Nobel to the behavioral economist and author of 'Nudge', Richard Thaler, in 2017 (Thaler \& Sunstein, 2008), and to the experimental economists, Michael Kremer, Abhijit Banerjee and Esther Duflo, in 2019 (Banerjee \& Duflo, 2012), highlights the rapidly increased relevance of behavioral approaches in both science and policy.

Researchers argue that behavioral public policy is at the core of a debate that challenges some foundational principles and conceptualizations of public policy. Set against the rationalist, 
utilitarian orientation 'which has been generally pervasive in the policy sciences from the very founding of the discipline' (Howlett, 2019, p. 80), nudging and related concepts are addressing the limits of rationality by targeting biases in human behavior. In this way, applications of behavioral economics and behavioral psychology may help to 'undermine the utilitarian paradigm' (Howlett, 2019, p. 80 ) and to strengthen the non-utilitarian tradition in public policy. Others are sceptical: Kahneman and Tversky were particularly successful because they found their way into mainstream economics by accepting the model of 'homo economicus' as a benchmark for identifying biases in behavior (Graf, 2019; Sent, 2004). Critics argue that behavioral public policy could have far-reaching consequences for democracy by dismissing citizens' preferences as biases and by offering both policy elites and experts a way to realize their goals (Schubert, 2017). With its critique of public deliberation as amplifying individual and collective biases (Sunstein, 2004b), behavioral public policy could even slowly come to replace the classical procedures of deliberative democracy (Straßheim, 2020). According to this view, behavioral public policy might even lead to a continuation of the technocratic tradition and its 'politics of expertise' (Fischer, 1990).

Following the call once made by Lasswell, this article takes the global rise of behavioral public policy as an 'opportunity for prolonged self-scrutiny' (Lasswell, 1977 [1930], p. 201). What can we learn regarding the foundations of both rationality and reasoning in public policy? More specifically, what insights can be gained concerning the role of expertise, the relation between knowing and governing and the distribution of 'epistemic competences' in public policy (Fischer, 2009; Goodin \& Spiekermann, 2018)? Conceptually, this paper is anchored in theories of 'political epistemology' (Fischer, 2009; Jasanoff, 2012; Straßheim, 2015; Turner, 2007). These theories are aimed at reconstructing the various ways and mechanisms by which both knowledge-making and decision-making are intertwined. They ask about the multiple practices which connect claims of validating and justifying beliefs about the world to claims of collectively ordering it. While 'objectivist epistemologies' (Majone, 1989) might hope for a rationalization of politics by science, political epistemologies are more careful. Proponents assume that, depending on the collective configurations and institutional contexts of policy-making, there are always multiple and potentially contested ways of how science and politics interact and how rationality is defined (Straßheim, 2015). Empirically, this contribution is based on an extensive review of research literature and of multiple primary sources such as policy papers, guidelines, annual updates and thematic reports issued by more than 60 behavioral public-policy units all over the world. Moreover, this material was used to identify cooperative relations and interactions between different behavioral public-policy units, such as conferences, collaborative workshops, common projects or advisory relations. These links were collected to get a better understanding of the global collaborations of behavioral expertise (for a preliminary analysis, see Botzem \& Straßheim, 2016).

The next section of this article takes a closer look at the networks of behavioral expertise and policy across countries and policy areas. This lays the foundation for an assessment of the various mechanisms that contribute to the emergence and the shape of expert communities and the fabrication of behavioral insights under the conditions of the 'postnational constellation' (Habermas, 2001). I will then discuss some recent findings concerning the symbiosis between science and policy in the context of 'evidence-based policy' and the implications that this has for policy pathologies and failures. Following this, the implications of behavioral perspectives regarding the relations between policy elites, experts and citizens in democracies will be explored. Finally, I will outline some public-policy possibilities beyond behavior. I suggest breaking free from the microfocus proposed by behavioral public policy and paying more attention to collective and cultural constellations of knowledge- and decision-making in democracies. 


\section{Global Expertise and the Fabrication of Public Policy}

The landscape of behavioral public policy is extremely diverse (Whitehead, Jones, \& Pykett, 2019). Transnational organizations, such as the World Bank, the European Commission and the United Nations, are using behavioral insights across a large and diverse spectrum of policy areas. In the United Kingdom, the rise of behavioral public policy is associated with the creation of the Behavioral Insights Team (BIT) by David Cameron in 2010, an organisation that has gained both national and international influence by experimentally developing and disseminating behavioral interventions (Jones, Pykett, \& Whitehead, 2013). It has become a paradigmatic example, cooperating and consulting with similar project units in other countries, such as the former Social and Behavioral Sciences Team (SBST) at the White House, the New South Wales Department of Premier and Cabinet Behavioral Insights Unit (NSW BIU) in Australia and the project group, Wirksam Regieren ('governing effectively') at the German chancellery. In Denmark and Norway, 'nudge units', such as iNudgeyou or Greenudge, engage in research projects focusing mainly, but not exclusively, on environmental policy and public health, such as reducing food waste, changing littering behavior or decreasing smoking.

An overview of behavioral-expert organizations across the world shows that the 'varieties of behavioral public policy' are multifaceted and complex (for the following, see Botzem \& Straßheim, 2016; Straßheim \& Beck, 2019). Three major developments are characteristic of the past 10 years: In a first phase of interaction and institutionalization between 2010 and 2012, several British government departments established small behavioral-research teams. At that time, the BIT had already developed well-established contacts with the US Office of Information and Regulatory Affairs (OIRA), the central unit reviewing the executive branch regulations, headed by Cass Sunstein from 2009 to 2012. In particular, David Halpern, formerly at the Cabinet Office Strategy Unit (COSU) and now head of BIT, worked as a kind of policy entrepreneur by keeping close relations not only with OIRA but also with the Scandinavian forerunners of the behavior-policy movement. At the European level, the BIT was interlinked with a small group of behavioral specialists at the Institute for Health and Consumer Protection in the European Commission's Joint Research Centre. Around 2012, the BIT started several longterm partnerships with other early adopters, such as the Government of New South Wales in Australia and the Ministry of Manpower in Singapore. A second phase of standardization and internationalization between 2014 and 2018 can be characterized by the international emergence of new behavioral-expertise organizations and by the expansion of existing links and collaborations. The number of staff at the BIT has grown impressively, especially since its partial privatization in 2014. Multiple international partnerships have been established between the BIT and, for example, the Behavioral Insights Network in the Netherlands (2014), the Mexican Ministry of Finance (2016) and the New York City Housing Authority (2016). Other behavioral units are also multiplying their collaborations with national, international and transnational actors. In a third phase of diversification since 2018, it has become clear that behavioral science is operating in, and embedded in, complex regulatory regimes consisting of multi-level, decentralized procedures, interactions between states and networks of non-state actors and multiple modes of societal coordination. As in the Dutch case, these may collaborate in a loose form of informal networks, knowledge-exchange groups, working groups or strategic projects (Feitsma, 2019). Inter- and transnational organizations, such as the United Nations Children's Fund, the World Health Organization and the United Nations Population Fund, but also NGOs and multinational organizations, such as the Abdul Latif Jameel Poverty Action Lab (J-Pal), are playing an important role in the spread of behavioral approaches in different regions of the Global South. 
Particularly in the early phase, behavioral expertise seems to have formed an epistemic community (John, 2018; Zito, 2018). Following the criteria developed by Haas and others (Haas, 2013, 351-352), an inter- and transnationally active circle of behavioral experts has formed a 'knowledge-based community with an authoritative claim to policy-relevant knowledge' (2013, 351-352). Members such as Sunstein, Thaler or Halpern 'share knowledge about the causation' of biases in citizens' behavior, as well as a 'common set of normative beliefs' $(2013,351)$ about the interventions and tools that might help to de-bias public policy (D. Halpern, 2016; Thaler \& Sunstein, 2008). Despite some differences in interpretation of the scientific and political implications, this circle was based on principled beliefs about the need to translate insights from behavioral economics and psychology into public policy.

The idea that 'all tools are informational now' (John, 2013), however, holds together an increasingly large collective of highly diverse actors that goes far beyond the clear-cut belief system of an epistemic community. During the past few years, behavioral re-design of policy instruments has covered an ever broader spectrum (Howlett, 2019; Loer, 2019; Oliver, 2015). This multifaceted industry that produces behavioral interventions is increasingly divergent in terms of principled beliefs, modes of validation, problem definitions and even policy solutions.

Simons and Voss (2018) have suggested interpreting such arrangements as instrument constituencies'. In instrument constituencies, tools such as emission-trading become the vantage point for forming and holding the collective together. Embedded in a 'web of practices', such as instrument design, experimentation, training, standardization and implementation, these tools bring together actors from very different backgrounds. As instruments are constituted and shaped by multiple actors, they also actively shape and 'nurture' the collective that emerges from these activities. Simons and Voss have made it clear that instrument constituencies are not based on core beliefs. Instead, the instruments themselves both constitute and catalyse the formation of relations between heterogeneous practices by experts and instrument designers, policy-makers and civil servants, consultants and civil-society organizations. Instrument constituencies provide solutions chasing problems (Béland, Howlett, \& Mukherjee, 2018; Voss \& Simons, 2014). They go against the grain of rationalist and functionalist assumptions about the problem-solving perspective in public policy. The instrument constituency comes to life and works as a collective by searching for problems for an already existing solution.

Indeed, behavioral public policy follows a very similar logic. Especially in the second phase of standardization and internationalization, blueprints of behavioral tools travel to very different contexts where they are implemented and reproduced by highly divergent sets of actors. Global standards and practices of professionalization transform the small community of experts into a global industry of policy instruments. Findings on pension defaults, tax-collection letters, university-application programmes, or reducing prescription errors, are presented in simple bar charts, demonstrating the efficiency of behavioral instruments. The success of such tools is instantly graspable. They establish a kind of politico-epistemic interlinkage in which actor groups, behavioral evidences and practices of validating and implementing indeed exist 'for and by' behavioral instruments (Voss \& Simons, 2014, p. 4).

Professionals who engage in the 'common policy enterprise' (Haas, 2013) of de-biasing society may still be active, but they are slowly integrated into a constituency of professionals and procedures that primarily design behavioral policy tools and constantly work at identifying suitable problems for this purpose. When looked at closely, the principled beliefs and notions of behavioral professionals are highly divergent (John \& Stoker, 2019). The original epistemic community, it seems, may have 'failed successfully' by laying the ground for, and later giving 
way to, a much larger collective encompassing a high diversity of policy actors and competing discourses. This is indeed the 'irony for experts - their foundational knowledge opens the door to myriad actors and contending interpretations' (Dunlop, 2017a, 228). The next two sections discuss some of the consequences of the behavioral constituency coming to life.

\section{Knowledge- and Decision-making Reconsidered}

The research carried out by Kahneman and Tversky was originally motivated by the question of how the intuition of experts and professionals works (Kahneman, 2011). This question, however, seems to have faded away in the debate about nudging. In their reports on the role of behavioral insights in development policy, both the World Bank (2015) and the United Nations (2016) have shifted the attention back to the following question: What are the cognitive limitations and biases of experts and decision-makers (for the following, see Straßheim, 2019a)? The most recent report by the Behavioral Insights Team on 'behavioral government' argues that elected and unelected officials are themselves influenced by the same heuristics and biases that they try to address (Hallsworth, Egan, Rutter, \& McCrae, 2018). Integrating a large corpus of already existing policy literature on the problem, the report identifies a multiplicity of decision-making biases (Bellé, Cantarelli, \& Belardinelli, 2018; Bovens \&'t Hard, 2016; Sheffer, Loewen, Soroka, Walgrave, \& Shaefer, 2018):

- Politicians and civil servants choose risky policies depending on how problems are presented (framing effects);

- Independently of their importance, certain issues and solutions are more salient than others to policy actors, leading to overreactions and the neglect of less visible but potentially more challenging problems (attention and salience);

- Professionals in governments have a tendency both to perceive and interpret evidence in line with existing views (confirmation bias);

- In groups, people tend to self-censor and conform to the group-majority view, while the arguments of other groups are rejected (group reinforcement and inter-group opposition);

- The more people are in favour of a policy, the more they assume that others have similar views (illusion of similarity);

- Decision-makers might overestimate the likelihood of future success and their ability to control outcomes (optimism bias and illusion of control).

Lodge and Wegrich call this the 'rationality paradox of nudging': '[A]t the heart of nudge is a basic paradox: It assumes bounded rationality, but offers a comprehensive vision of rationality to address problems caused by bounded rationality' (Lodge \& Wegrich, 2016, p. 253). While nudge and other behavioral public policies show awareness of the cognitive limitations of citizens, proponents seem to be too optimistic on the decision-making capacities of nudgers themselves. The BIT (Hallsworth et al., 2018, p. 11-12) suggests strategies to overcome these biases, such as transparency about the evidence base used, the building of networks to access expert advice and insight, the assembling of teams that are cognitively diverse, or the integration of experimental trials into policy execution 'wherever possible'.

The call for an even more systematic integration of experimental evidence, however, seems also to be somewhat over-optimistic. As 'gold standard' randomized controlled trials (RCT) have become the universal currency for evaluating policies, Behavioral interventions are tested in 
experimental or quasi-experimental designs, comparing treatment groups and control groups. The global wave of RCTs, managed by organizations such as the Behavioral Insights Team (BIT) in the UK, or the Abdul Latif Jameel Poverty Action Lab (J-Pal) in the US, has already raised some criticism (Donovan, 2018; Pearce \& Raman, 2014). RCTs create a controlled environment in which the social and cultural context is bracketed out in favour of internal validity. Or, in the pointed judgement made by Deaton and Cartwright: 'RCTs are not capable of telling us what would happen if these policies were implemented to scale, of capturing unintended consequences that typically cannot be included in the protocols, or of modelling what will happen if schemes are implemented by governments [...].' (Deaton \& Cartwright, 2016, p. 61). The implicit premise of RCTs is their micro-instrumentalism, i.e. their myopic focus on tools that target individual behavior as a unit of analysis. RCTs assume that 'small' instruments - adding a specific sentence to a tax letter or changing the design of pension enrolments - are superior to macro-level, structural interventions (M. Halpern \& Mason, 2015).

The call for RCTs to be a means of de-biasing behavioral government reflects the widespread belief in evidence-based policy-making as a way of depoliticizing ideologically loaded problems and identifying the most effective policy instruments. Many studies, however, have shown that the use of evidence to trigger mechanisms of policy learning is not enough to prevent policy failures (Dunlop, 2017b; Straßheim \& Kettunen, 2014). One reason is that scientific experts are not immune to those biases that the BIT has identified in policy-making. Just like policy-makers, they are prone to cognitive and collective biases such as framing effects, confirmation biases or an illusion of control (Dunlop \& Radaelli, 2015; Kahneman, 2011; Tetlock, 2005). More problematic, however, may be the collective biases that can result from the interaction between experts and policy-makers. While scientific experts often try to 'draw an artificial line between facts and values, or science and policy', understanding the mechanisms that are closing the 'science-policy gap' could be essential for understanding behavioral public-policy failures (Wellstead, Cairney, \& Oliver, 2018, p. 2). Research on expertise and policy advice has identified the multiple mechanisms of symbiosis or 'co-production' that may lead to technocratic tendencies, a collective black-boxing of complex contexts, a silent depoliticization of value-loaded questions and a mutual reinforcement of political and epistemic authority (Boswell, 2009; Kennedy, 2016; Koppl, 2018; Straßheim, 2018). This may lead to a collective illusion of control (Dunlop \& Radaelli, 2015) among experts and policy actors, reinforced by the unquestionable and undeniable evidence of experimental trials. In complex policymaking environments, these mechanisms of science-policy 'groupthink' may lead to a de-politicized and de-contextualized view of policy-making (Wellstead et al., 2018). Despite the seemingly neutral perspective of evidence-based policy, behavioral approaches may have mobilized an elitist discourse on deliberative democracy.

\section{Against Democracy?}

Part of the discourse on behavioral public policy is also a critique of democratic deliberation (for the following, see Straßheim, 2020; Crouch, 2004). Repeatedly, some of its proponents have argued against democratic deliberation as a mode of decision-making, pointing to collective biases and 'reasoning failures': 'Those who practice deliberation, or celebrate it, have not adequately engaged with existing knowledge, both theoretical and practical, about how individuals and groups actually behave' (Sunstein, 2006, p. 221). In the past decade, behaviorally informed studies have continuously pointed to multiple psychological and cognitive mechanisms leading to failures in deliberation and democratic procedures (Button, 2018; Rogers, Fox, \& Gerber, 2013; Sunstein, 2004a, 2004b, 2006): In group deliberation, pre-existing errors 
are amplified instead of corrected. Informational and reputational cascades lead people to follow the actions of their predecessors. Political participation may suffer from group polarization and the interaction between like-minded people with the consequence that participants in debates and public fora shift their attitudes in accordance with group pressures. Extreme positions that existed before the deliberation process are amplified and group polarization is increased. Learning might be limited because shared information is crowding out unshared information. In a similar way, voting behavior is seen as being influenced by social pressure and social norms, social-identity dynamics and cognitive dissonance.

Based on these and other observations derived from psychological and behavioral experiments, Sunstein comes to the conclusion that 'the mechanisms that underlie group polarization raise serious questions about the view that deliberation is likely to yield correct answers to social questions' (Sunstein, 2000, 118). As a consequence, nudges and other behavioral micro-interventions are recommended to 'de-bias' deliberative democracy and activate citizens' voting motivation in elections (John, 2018; Rogers et al., 2013; Williams, Allpress, \& Rootham, 2018). Instead of engaging in deliberation procedures, advocates of behavior strategies recommend nudges in multiple areas such as health, environment and sustainability, or welfare to work. To avoid biased deliberation in collectives, deliberation itself is individualized: 'The argument is that an enhanced nudge is much more desirable than full-on deliberation, which takes up too much time, assumes too much capacity, and only selects a minority of the population' (John, 2018, 122-134). As Thomas has shown, behavioral public policy thus implicitly introduces a notion of rational asymmetry between biased citizens and nearly omniscient experts and policymakers (Thomas, 2019, p. 12).

Critics argue that behavioral public policy could have far-reaching consequences for democracy (Straßheim \& Beck, 2019; Thomas, 2019): Because deliberation procedures are increasingly perceived as amplifying cognitive distortions in collectives, modes of cognitive and behavioral correction by both policymakers and experts are slowly replacing the classical procedures of deliberative democracy. Analysing the 'political economy' of nudging, Schubert assumes that citizens' preferences can more easily be dismissed as biases while they offer policy elites a way to realize their goals (Schubert, 2017). When these elite preferences are implemented through nudges, they might be less visible, less controllable and less likely to become the topic of political debates or conflicts. Moreover and as already discussed above, policymakers and experts themselves are not free from cognitive limitations and could even mutually reinforce each other in biasing the policy process (Koppl, 2018).

These problems of biased decision-making also enhance the 'risk of cognitive capture by experts' (Thomas, 2019, p. 17). Policy advisors might be influenced by alterations in their very own choice architecture, e.g. by consultancies or agencies 'legislating in the shadows' by providing evidence and interpretative assistance in drafting legislation (Walker, 2017). Finally, the reliance on expertise in policymaking could result in epistemic monopolies, undermining the mechanisms of knowledge diversification in democracies and underestimating the value of local and contextual knowledge (Thomas, 2019, p. 18-22). From a critical perspective, it could be argued that the project of de-biasing democracy has its own biases.

It seems that the debate on behavioral public policy has already changed the interpretation of democratic deliberation. Drawing on insights from behavioral studies, authors such as Brennan are explicitly arguing 'against democratic triumphalism' (Brennan, 2016; see also Khanna, 2017). Instead, a technocratic instrumentalism is proposed, which values effectiveness and 'epistocracy' as means of correcting the biases and irrationalities of collective decision-making. 
Epistocracy, the 'rule of the knowledgeable' (Brennan, 2016), takes the asymmetries between the biased and the unbiased (or de-biased), proposed by behavioral approaches, seriously. Proponents are suggesting establishing the right for expert bodies to veto rules passed by democratic bodies ('epistocratic veto'), to restrict suffrage to those who are competent or sufficiently well-informed ('restricted suffrage') and to weight the votes of citizens based on their 'objective political knowledge' proved by the ability to pass a knowledge test ('weighted voting') (Brennan, 2016). Behavioral forerunners such as Singapore may provide ample evidence that some of these post-democratic ideas are already part and parcel of political practices (Khanna, 2017; Low, 2012).

In most countries, current behavioral public policy is far away from this kind of political instrumentalism. It has helped in understanding some of the limits and side-effects of deliberation and informed the critical discussion on deliberative democracy (Hendriks, 2019). It has also evolved conceptually and developed a complex understanding of the potential of subjects for action, learning and reflection in a social environment (John, 2018; Sunstein \& Reisch, 2019). Its protagonists should, however, be well aware of the post-democratic tendencies that the behavioral discourse has already mobilized under the conditions of global communication.

\section{Conclusions: Beyond Behavior}

Experts and policy-makers may pave the way to new forms of democratic self-governance. As the case of behavioral expertise and public policy shows, however, they might also empower actors that favour technocratic and epistocratic ideas of governance in the hope that the flaws of democratic systems can be overcome by a more rational 'rule of the knowledgeable' (Brennan, 2016). Experts and professionals should be well aware of the normative implications of their work - and of the fact that, especially under the conditions of the post-national constellation, the instruments they are proposing might develop a political life of their own. Adler and Haas have pointed to this self-undermining mechanism when they are arguing that communities of experts 'create reality, but not as they wish' (Adler \& Haas, 1992, p. 381).

The case of behavioral public policy may also provide some general lessons for public policy. It might be important to shift the attention again from individual behavior to the conditions of collective action. Mirroring the decades of debate on the psychological and cognitive foundations of decision-making, some authors seem to equate public policy mostly with both channelling and changing behavior (Anderson, 2014; Knoepfel, Larrue, Varone, \& Hill, 2011, p. 26). Public policy, however, needs to break free from the micro-focus proposed by behavioral economics and to pay more attention to institutional, cultural and discursive dynamics (Howlett, 2019; Straßheim, 2020). Lasswell was already well acquainted with the mechanisms and problems of collective action. His contextual orientation included group dynamics, institutions, symbols, cultural configurations and long-term dynamics in a historical perspective. Science and politics would always have to search for 'cultural patterns in terms of their human consequences' (Lasswell, 1977 [1930], p. 200). Some of the failures and side-effects of nudging and other behavioral-change strategies are a direct outcome of the methodological and conceptual shortcomings of an undersocialized perspective. Even more problematic, however, are those mechanisms leading to collective failures and myopia in the relationship between science and policy. RCTs and the quest for ever more robust and value-free evidence are one expression of these pathological mechanisms in the science-policy nexus. Finding ways to overcome such biases and to develop 'regulatory humility' (Dunlop \& Radaelli, 2015) could be more important than ever. 


\section{Bibliography}

Adler, E., \& Haas, P. M. (1992). Conclusion: Epistemic communities, world order, and the creation of a reflective research programm. International Organization, 46(1), 367-390.

Anderson, J. E. (2014). Public Policymaking. Stamford: Cengage Leraning.

Banerjee, A. V., \& Duflo, E. (2012). Poor Economics. A radical rethinking of the way to fight global poverty New York: Public Affairs.

Béland, D., Howlett, M., \& Mukherjee, I. (2018). Instrument constituencies and public policy-making: an introduction. Policy and Society, 37(1), 1-13.

Bellé, N., Cantarelli, P., \& Belardinelli, P. (2018). Prospect theory goes public: Experimental evidence on cognitive biases in public policy and management decisions. Public Administration Review, 78(6), 828-840.

Boswell, C. (2009). The Political Uses of Expert Knowledge. Immigration Policy and Social Research. Cambridge: Cambridge University Press.

Botzem, S., \& Straßheim, H. (2016). On Her Majesty's Service? The Behavioural Insights Team and its role in the global rise of behavioural change policies (Paper for the 44th ECPR Joint Sessions 2016, Workshop No. 2: Behavioural Change and Public Policy). Berlin/Bremen.

Bovens, L., \& 't Hard, P. (2016). Revisiting the study of policy failures. Journal of European Public Policy, 23(5), 653-666.

Brennan, J. (2016). Against Democracy. Princeton: Princeton University Press.

Button, M. E. (2018). Bounded Rationality without Bounded Democracy: Nudges, Democratic Citizenship, and Pathways for Building Civic Capacity. Perspectives on politics, 16(4), 1034-1052.

Crouch, C. (2004). Post-Democracy. Cambridge/Malden: Polity Press.

Deaton, A., \& Cartwright, N. (2016). Understanding and misunderstanding randomized controlled trials (NBER Working Paper, no. 22595). Princeton: Princeton University.

Donovan, K. P. (2018). The rise of the randomistas: on the experimental turn in international aid. Economy and Society, 47(1), 27-58.

Dunlop, C. A. (2017a). The irony of epistemic learning: epistemic communities, policy learning and the case of Europe's hormones saga. Policy and Society, 36(2), 215-232.

Dunlop, C. A. (2017b). Policy learning and policy failure: definitions, dimensions and intersections. Policy \& Politics, 45(1), 3-18.

Dunlop, C. A., \& Radaelli, C. M. (2015). Overcoming Illusions of Control: How to Nudge and Teach Regulatory Humility. In A. Alemanno \& A.-L. Sibony (Eds.), Nudge and the Law. A European Perspective (pp. 139-160). Oxford/London: Hart.

Feitsma, J. (2019). Inside the Behavioural State. Utrecht: eleven international publishing.

Fischer, F. (1990). Technocracy and the Politics of Expertise. Newbury Park/London/New Delhi: Sage.

Fischer, F. (2009). Democracy \& Expertise. Reorienting Policy Inquiry. Oxford: Oxford University Press.

Goodin, R. E., \& Spiekermann, K. (2018). An Epistemic Theory of Democracy. Oxford: Oxford University Press. 
Graf, R. (2019). Nudging before the nudge? Behavioural traffic safety regulation and the rise of behavioural economics. In H. Straßheim \& S. Beck (Eds.), Handbook of Behavioural Change and Public Policy (Handbooks of Research on Public Policy, ed. by Frank Fischer) (pp. 23-37). Cheltenham, UK/ Northampton, MA: Edward Elgar.

Haas, E. B. (2013). Epistemic Communities. In J. Krieger (Ed.), The Oxford Companion to Comparative Politics (Volume 1) (pp. 351-359). Oxford/New York: Oxford University Press.

Habermas, J. (2001). The Postnational Constellation. Cambridge: MIT Press.

Hallsworth, M., Egan, M., Rutter, J., \& McCrae, J. (2018). Behavioural Government. Using behavioural science to improve how governments make decisions. London: Behavioural Insights Team,.

Halpern, D. (2016). Inside the Nudge Unit: How small changes can make a big difference. London: WH Allen.

Halpern, M., \& Mason, D. (2015). Radical Incrementalism. Evaluation, 21(2), 143-149.

Hendriks, F. (2019). Democratic innovation beyond deliberative reflection: the plebiscitary rebound and the advent of action-oriented democracy. Democratization, 26(3), 444-464.

Howlett, M. (2019). Matching policy tools and their targets: beyond nudges and utility maximization in policy design. In H. Straßheim \& S. Beck (Eds.), Handbook of Behavioural Change and Public Policy (Handbooks of Research on Public Policy, ed. by Frank Fischer) (pp. 78-90). Cheltenham, UK/ Northampton, MA: Edward Elgar.

Jasanoff, S. (2012). Science and Public Reason. New York: Routledge.

John, P. (2013). All tools are informational now: how information and persuasion define the tools of government. Policy \& Politics, 41(4), 605-620.

John, P. (2018). How Far to Nudge? Assessing Behavioural Public Policy Cheltenham, UK/Northampton, MA: Edward Elgar.

John, P., \& Stoker, G. (2019). Rethinking the role of experts and expertise in behavioural public policy. Policy \& Politics, 47(2), 209-225.

Jones, R., Pykett, J., \& Whitehead, M. (2013). Changing Behaviours. On the Rise of the Psychological State. Cheltenham, UK/Northampton, MA: Edward Elgar.

Kahneman, D. (2011). Thinking, Fast and Slow. London: Penguin Books.

Kennedy, D. (2016). A World of Struggle. How Power, Law, and Expertise Shape Global Political Economy. Princeton/Oxford: Princeton University Press.

Khanna, P. (2017). Technocracy in America: Rise of the Info-State. Singapore: CreateSpace.

Knoepfel, P., Larrue, C., Varone, F., \& Hill, M. (2011). Public Policy Analysis. Chicago: The University of Chicago Press.

Koppl, R. (2018). Expert failure. New York: Cambridge University Press.

Lasswell, H. D. (1951). Democratic Character. In H. D. Lasswell (Ed.), The Political Writings of Harold D. Lasswell (pp. 465-525). Glencoe: Free Press.

Lasswell, H. D. (1977 [1930]). Psychopathology and Politics. Chicago: University of Chicago Press.

Lindblom, C. (1959). The Science of Muddling Through. Public Administration, Review(19), 79-88.

Lodge, M., \& Wegrich, K. (2016). The Rationality Paradox of Nudge: Rational Tools of Government in a World of Bounded Rationality. Law \& Policy, 38(3), 250-267. 
Loer, K. (2019). The enzymatic effect of behavioural sciences: what about policy-maker's expectations? In H. Straßheim \& S. Beck (Eds.), Handbook of Behavioural Change and Public Policy (Handbooks of Research on Public Policy, ed. by Frank Fischer) (pp. 180-195). Cheltenham, UK/Northampton, MA: Edward Elgar.

Low, D. (2012). Behavioural Economics and Policy Design - Examples from Singapore. Singapore: World Scientific Publishing.

Majone, G. (1989). Evidence, Argument, and Persuasion in the Policy Process. New Haven/London: Yale University Press.

OECD. (2017). Behavioural Insights and Public Policy: Lessons from Around the World. Paris: OECD Publishing.

Oliver, A. (2015). Nudging, Shoving, and Budging: Behavioural Economic-Informed Policy. Public Administration, 93(3), 700-714.

Pearce, W., \& Raman, S. (2014). The new randomised controlled trials (RCT) movement in public policy: challenges of epistemic governance. Policy Science, 47, 387-402.

Rawat, S. (2019). A bibliometric analysis of behavioural studies in economics and public policy journals. In H. Straßheim \& S. Beck (Eds.), Handbook of Behavioural Change and Public Policy (Handbooks of Research on Public Policy, ed. by Frank Fischer) (pp. 49-62). Cheltenham, UK/Northampton, MA: Edward Elgar.

Rogers, T., Fox, C. R., \& Gerber, A. S. (2013). Rethinking Why People Vote: Voting as Dynamic Social Expression. In E. Shafir (Ed.), The Behavioral Foundations of Public Policy (pp. 91-107). Princeton: Princeton Univ. Press.

Schubert, C. (2017). Exploring the (behavioural) political economy of nudging. Journal of Institutional Economics, 13(3), 499-522.

Sent, E.-M. (2004). Behavioral Economics: How Psychology Made Its (Limited) Way Back Into Economics. History of Political Economy, 36(4), 735-760.

Sheffer, L., Loewen, P., Soroka, S., Walgrave, S., \& Shaefer, T. (2018). Select nonrepresentative representatives: An experimental study of the decision making of elected politicians. American Political Science Review, 112(2), 302-321.

Simon, H. A. (1957). Models of Man: Social and Rational- Mathematical Essays on Rational Human Behavior in a Social Setting. New York: Wiley.

Simons, A., \& Voss, J.-P. (2018). The concept of instrument constituencies: accounting for dynamics and practices of knowing governance. Policy and Society, 37(1), 14-35.

Straßheim, H. (2015). Politics and policy expertise: towards a political epistemology. In F. Fischer, D. Torgerson, A. Durnová, \& M. Orsini (Eds.), Handbook of Critical Policy Studies (pp. 319-340). Cheltenham, UK/Northampton, MA: Edward Elgar.

Straßheim, H. (2018). Policy as a body of expertise. In H. K. Colebatch \& R. Hoppe (Eds.), Handbook on Policy, Process and Governing (pp. 89-108). Cheltenham, UK/Northampton, MA: Edward Elgar.

Straßheim, H. (2019a). Behavioural mechanisms and public policy design: preventing failures in behavioural public policy. Public Policy and Administration.

https://doi.org/10.1177/0952076719827062

Straßheim, H. (2019b). Lasswell's legacy revisited: critical perspectives on psychological and behavioural public policy. Critical Policy Studies, 13(2), 221-225. 
Straßheim, H. (2020). De-biasing Democracy. Behavioural public policy and the post-democratic turn. Democratization, 27(3), 461-476.

Straßheim, H., \& Beck, S. (Eds.). (2019). Handbook of Behavioural Change and Public Policy (Handbooks of Research on Public Policy, ed. by Frank Fischer). Cheltenham, UK/Northampton, MA: Edward Elgar.

Straßheim, H., Jung, A., \& Korinek, R.-L. (2015). Reframing Expertise: The Rise of Behavioural Insights and Interventions in Public Policy In A. Berthoin Antal, M. Hutter, \& D. Stark (Eds.), Moments of Valuation. Exploring Sites of Dissonance (pp. 249-268). Oxford: Oxford University Press.

Straßheim, H., \& Kettunen, P. (2014). When does evidence-based policy turn into policy-based evidence? Configurations, contexts and mechanisms. Evidence \& Policy, 10(2), 259-277.

Sunstein, C. R. (2000). Deliberative Trouble - Why Groups Go to Extremes. Yale Law Journal, 110, 71-119.

Sunstein, C. R. (2004a). Four Failures of Deliberating Groups (Public Law and Legalt Theory Working Paper No. 215). Chicago: University of Chicago.

Sunstein, C. R. (2004b). Group Judgments: Deliberation, Statistical Means, and Information Markets (Public Law and Legal Theory Working Paper No. 72). Chicago: University of Chicago.

Sunstein, C. R. (2006). Infotopia: How Many Minds Produce Knowledge. Oxford/New York: Oxford University Press.

Sunstein, C. R., \& Reisch, L. A. (2019). Trusting Nudges: Toward A Bill of Rights for Nudging (Routledge Advances in Behavioural Economics and Finance). Oxon/New York: Routledge.

Tetlock, P. E. (2005). Expert Political Judgement. How Good Is It? How Can We Know? Princeton/Oxford: Princeton Univ. Press.

Thaler, R. H., \& Sunstein, C. R. (2008). Nudge. Improving Decisions About Health, Wealth and Happiness. London: Penguin Books.

Thomas, M. D. (2019). Reapplying behavioural symmetry: public choice and choice architectures. Public Choice, 180, 11-25.

Torgerson, D. (2019). Lasswell in the looking glass: a 'mirror' for critical policy studies. Critical Policy Studies, 13(1), 122-130.

Turner, S. (2007). Political Epistemology, Experts, and the Aggregation of Knowledge. Spontanous Generation, 1(1), 36-47.

United Nations. (2016). Behavioural Insights at the United Nations. Achieving Agenda 2030. New York: United Nations Development Program.

Voss, J.-P., \& Simons, A. (2014). Instrument constituencies and the supply side of policy innovations: the social life of emmissions trading. Environmental Politics, 23(5), 735-754.

Walker, C. J. (2017). Legislating in the shadows. University of Pennsylvania Law Review, 165, 13771433.

Wellstead, A., Cairney, P., \& Oliver, K. (2018). Reducing ambiguity to close the science-policy gap.

Policy Design and Practice, 1(2), 115-125

https://doi.org/10.1080/25741292.2018.1458397 
Whitehead, M., Jones, R., \& Pykett, J. (2019). Nudging around the world: a critical geography of the behaviour change agenda. In H. Strassheim \& S. Beck (Eds.), Handbook of Behavioural Change and Public Policy (Handbooks of Research on Public Policy series) (pp. 90-101). Cheltenham, UK/Northampton, MA: Edward Elgar.

Williams, M., Allpress, J., \& Rootham, E. (2018). Increasing Voter Turnout Using Behavioural Insights (TR2018/006): Aukland Council.

World Bank. (2015). Mind, Society and Behavior. Washington: World Bank.

Zito, A. R. (2018). Instrument constituencies and epistemic community theory. Policy and Society, 37(1), 36-58. 